\title{
Perbezaan kualiti hidup penduduk berdasarkan ciri demografi di pusat petempatan kecil: Kajian kes daerah Muallim, Perak, Malaysia
}

\author{
Yazid Saleh, Hanifah Mahat, Mohmadisa Hashim, Nasir Nayan, \\ Saiyidatina Balkhis Norkhaidi \\ Jabatan Geografi dan Alam Sekitar, Fakulti Sains Kemanusiaan, \\ Universiti Pendidikan Sultan Idris, Tanjong Malim, Perak, Malaysia \\ *e-mel: yazid@fsk.upsi.edu.my
}

Received: 19 August 2019; Accepted: 19 May 2020; Published: 20 May 2020

To cite this article (APA): Saleh, Y., Mahat, H., Hashim, M., Nayan, N., \& Norkhaidi, S. B. (2020). Perbezaan kualiti hidup penduduk berdasarkan ciri demografi di pusat petempatan kecil: Kajian kes daerah Muallim, Perak, Malaysia. EDUCATUM Journal of Social Sciences, 6(1), 12-21. https://doi.org/10.37134/ejoss.vol6.1.2.2020

To link to this article: https://doi.org/10.37134/ejoss.vol6.1.2.2020

\begin{abstract}
Abstrak
Artikel ini bertujuan untuk meneliti perbezaan kualiti hidup penduduk dalam daerah Muallim dari berdasarkan tiga petunjuk sosial yang berbeza iaitu segi jantina, etnik dan tahap pendidikan. Dengan menggunakan soal selidik sebagai instrumen kajian, sejumlah 500 orang ketua isi rumah dari lima buah pusat petempatan kecil dalam daerah Muallim telah dipilih sebagai responden dengan menggunakan persampelan rawak bertujuan. Pemboleh ubah kualiti hidup penduduk yang dikaji adalah ekonomi, sosial dan alam sekitar. Analisis inferensi ujian-t digunakan bagi menganalisis sama ada terdapat perbezaan kualiti hidup dari segi jantina dan lokasi tempat tinggal penduduk manakala analisis ANOVA digunakan bagi menganalsis sama ada terdapat perbezaan kualiti hidup dari segi etnik dan tahap pendidikan tertinggi dalam setiap pemboleh ubah. Dapatan analisis ujian-t menunjukkan bahawa tidak terdapat perbezaan kualiti hidup yang signifikan antara jantina dari segi sosial dan alam sekitar manakala bagi lokasi pula terdapat perbezaan yang signifikan bagi ketiga-tiga pemboleh ubah kajian. Dapatan ANOVA pula menunjukkan terdapat perbezaan kualiti hidup bagi ketiga-tiga pemboleh ubah dari segi etnik dan tahap pendidikan tertinggi bagi ketiga-tiga pemboleh ubah kajian. Secara keseluruhannya dapat dirumuskan bahawa lokasi, etnik dan tahap pendidikan memberi peranan kepada kualiti hidup penduduk di Muallim namun tidak bagi jantina. Penemuan ini menunjukkan bahawa elemen jantina tidak memainkan peranan dalam mempengaruhi kualiti hidup penduduk di sesebuah kawasan.
\end{abstract}

Kata kunci: kualiti hidup, pusat petempatan kecil, sosial, ekonomi, alam sekitar, Muallim

\begin{abstract}
This article aims to examine the difference in the quality of life of the population in Muallim district based on three different social indicators, such as sex, ethnicity and education level. A set of questionnaires was used as a research instrument, and a total of 500 household heads from five small settlement centres in Muallim district were selected as respondents using purposive random sampling. The quality of life variables of the population studied are economic, social and environmental. T-test inference analysis was used to analyze whether there were differences in quality of life based on sex and residence. Meanwhile, ANOVA analysis was used to validate whether there were differences in quality of life in ethnicity and level of education in each variable. The results of t-test analysis revealed that there were no significant differences in quality of life between sex in terms of social and environmental factors. However, for location, there were significant differences among the three variables. The ANOVA results showed that there were differences in quality of life for all three variables in terms of ethnicity and higher education level for all three variables. In sum, it can be concluded that location, ethnicity and education level play a role in the quality of life of Muallim residence, but not the gender. These findings suggest that the gender element did not play a role in influencing the quality of life of a person in that particular area.
\end{abstract}

Keyword: quality of life, small settlement centre, social, economy, environment, Muallim 


\section{PENGENALAN}

Bandar dan petempatan kecil lazimnya menjadi tumpuan manusia menjalankan aktiviti ekonomi malahan turut berfungsi sebagai pusat penyediaan perkhidmatan di kawasan luar bandar kursusnya. Pembangunan fizikal dan aktiviti ekonomi semasa serta taburan populasi penduduk sesebuah kawasan tadahan memberi pengaruh kepada kekerapan penyediaan aktiviti ekonomi yang dijalankan (Rosmin, 2007). Menurut Katiman (2002), pembandaran merupakan suatu proses penumpuan penduduk mendiami sesuatu kawasan yang dianggap bandar. Kini, masyarakat lebih suka menetap di kawasan bandar kerana mobiliti kepada ruang ekonomi dan sosial lebih luas berbanding berada di luar bandar. Pencapaian Malaysia dalam menyediakan sistem pengangkutan jalan raya yang lebih moden dan berteknologi tinggi di bawah Sistem Lebuh Raya Malaysia membolehkan proses perbandaran di Malaysia semakin pesat berkembang. Kesan usaha ini telah mewujudkan pusat petempatan kecil di pinggir bandar atau sepanjang jalan pengangkutan utama mengikut fungsinya yang tertentu seperti bandar satelit, bandar baru, bandar peranginan, bandar universiti dan lain-lain lagi. Ini jelas menunjukkan sistem pengangkutan ini telah menyumbang kepada pembukaan sesebuah bandar (Wan Rozali, 2003). Dalam kes ini, pusat petempatan kecil tidak terkecuali.

Dari segi sejarah, sebahagian dari kecil bandar di Malaysia telah wujud sejak zaman penjajahan sebagai kawasan permulaan pembandaran serta sebagai pusat pengumpul hasil dan sumber bahan mentah terutamanya bijih timah. Selain itu, ada juga yang berperanan sebagai perantara antara kawasan luar bandar dengan kawasan bandar besar selain turut berfungsi dalam memasarkan barangan yang dihasilkan oleh kawasan luar. Dengan ini penduduk luar bandar tidak terasing dari pembangunan semasa melalui hubungan yang wujud melalui pusat petempatan kecil. Selain itu, pusat petempatan kecil ini juga berupaya menjadi tempat bagi penduduk mendapatkan barangan asas pertanian, keperluan harian dan juga peluang pekerjaan (Yazid et al., 2015).

Apabila membahaskan tentang pusat petempatan kecil, satu elemen yang sering dititikberatkan ialah kelestariannya (Knox \& Meyer, 2009). Berdasarkan pandangan Zaini (2009), kelestarian menekankan aspek sejagat dalam usaha memastikan alam sekitar terpelihara, bahkan membolehkan pertumbuhan ekonomi lebih stabil dan sesuai dengan keperluan asasi manusia. Secara lebih fokus, menurut Abd Samad, Shaharudin dan Abd Hadi (2004) kelestarian Bandar atau petempatan kecil boleh ditanggap sebagai sebuah petempatan yang masih lagi berada dalam satu proses pembentukan satu persekitaran binaan dengan keadaan ekonomi, sosial, politik dan persekitaran masyarakatnya berada dalam kesejahteraan.

Secara umumnya, matlamat kelestarian petempatan atau bandar kecil selalu mengalami perubahan mengikut keperluan semasa namun pada dasarnya terdapat tiga petunjuk atau indikator utama iaitu ekonomi, sosial dan alam sekitar (Fatimah et al., 2008) dalam mengukur sejauhmana kelestarian sesuatu petempatan itu. Ini turut merangkumi kemampuan penduduk untuk mendapat segala keperluan dan kemudahan yang disediakan adalah mencukupi dan dapat mempengaruhi kualiti hidup penduduk (Garau, 2018).

Menurut Ahmad Shukri dan Rosman (2003), kemajuan ekonomi membawa kepada peningkatan produktiviti pengeluaran hasil ekonomi dari sumber-sumber yang terhad kepada pengeluaran yang produktiviti tinggi. Ekonomi merupakan pengkajian tentang bagaimana sumber-sumber digunakan untuk memuaskan keperluan dan kehendak individu, masyarakat atau kelompok penghuni sesuatu tempat. Tahap keupayaan ekonomi berkait rapat dengan sumbangan faktor-faktor asas ekonomi merangkumi tenaga buruh, sumber modal, peranan usahawan dan faktor-faktor tanah. Perkembangan ekonomi bandar kecil secara lestari penting bagi mewujudkan suasana harmoni antara proses kemajuan ekonomi bandar dengan kualiti hidup penduduknya. Sekiranya perkembangan ekonomi bandar kecil tidak seiringan dengan proses perkembangan sosial maka tahap kelestarian proses petempatan ini masih tidak seimbang yang akhirnya keadaan ini akan memberi kesan kepada kemerosotan kualiti hidup penduduk bandar (Ahmad Shukri \& Rosman, 2003).

Alam sekitar juga merupakan faktor utama kepada kualiti hidup penduduk di sesebuah petempatan. Pembangunan petempatan yang lestari seharusnya mengambil kira keupayaan menampung, pengambilan sumber, pengagihan bahan buangan serta kadar pencemaran yang dihasilkan dalam bandar kecil dan kawasan sekelilingnya (White \& Whitney, 1992). Keadaan alam sekitar petempatan yang tidak tercemar dan asli memberi suasana tenang dan nyaman kepada penduduk. Alam sekitar menyumbang kepada kelestarian dengan menyeimbangkan keseimbangan antara proses pembangunan 
yang berlaku di kawasan petempatan. Apabila kelestarian petempatan atau bandar kecil adalah baik maka ini akan dapat mempengaruhi kualiti hidup penduduk di sesebuah petempatan itu. Kualiti hidup adalah melibatkan pelbagai disiplin, termasuk psikologi, perubatan, ekonomi, sains persekitaran dan dalam memenuhi keperluan asas fizikal, biologi, psikologi, ekonomi dan social (Zaimah et al., 2012). Dalam bahasa yang mudah ia merujuk kepada kepada kesejahteraan atau ketidaksejahteraan masyarakat dalam persekitaran.

\section{KUALITI HIDUP DAN FAKTOR DEMOGRAFI}

Dalam tempoh empat dekad yang lalu, Malaysia telah mencapai pertumbuhan pembangunan yang memberangsangkan dan Indeks Kualiti Hidup Malaysia (IKHM) telah dibangunkan pada tahun 1999 bagi membolehkan kemajuan negara diukur. Selaras dengan kemajuan Malaysia ke arah ekonomi berpendapatan tinggi, petunjuk IKHM diperkukuhkan dan dimantapkan dengan menukarkannya kepada Indeks Kesejahteraan Rakyat Malaysia (IKRM). IKRM telah dibangunkan berdasarkan petunjuk domestik yang juga diiktiraf di peringkat antarabangsa. Berdasarkan indeks kualiti hidup, pelbagai petunjuk telah disenaraikan secara menyeluruh melibatkan keperluan bagi menjamin kualiti hidup selaras dengan matlamat pembangunan negara. Antaranya termasuk sosioekonomi, kawasan persekitaran, perumahan, keadaan alam sekitar dan penyertaan sosial (Unit Perancangan Ekonomi, 2014).

Alat pengukur utama dalam menilai tahap kualiti sosial masyarakat ialah berdasarkan indeks kualiti hidup dengan pelbagai angkubah yang telah digariskan berdasarkan matlamat pembangunan negara. Angkubah yang terlibat dalam penilaian indeks kualiti hidup merangkumi tingkat pendapatan, persekitaran pekerjaan, pemilikan rumah, keadaan persekitaran, kehidupan keluarga dan penyediaan infrastruktur. Kualiti hidup sosial dan proses pembandaran merupakan petunjuk kepada ketamadunan manusia dalam pembangunan sesebuah negara. Peningkatan kualiti sosial masyarakat merupakan asas kepada penentuan tahap kemajuan dan kelestarian terhadap penghuninya. Melalui lima teras utama yang terkandung dalam Rancangan Malaysia ke Sembilan menekankan usaha meningkatkan tahap dan kemapanan kualiti hidup rakyat dengan menekankan kepada penyediaan keperluan asas dan penekanan kepada usaha-usaha menangani isu berhubung dengan penyelenggaraan, menaiktarafkan dan keberkesanan penggunaan sumber (Unit Perancang Ekonomi Jabatan Perdana Menteri, 2015).

Faktor demografi dilihat turut menjadi penentu kepada sesuatu tahap kesejahteraan dan kualiti hidup penduduk seperti faktor jantina, lokasi, etnik dan tahap pendidikan. Menurut Habibah dan Punitha (2012), terdapat perbezaan dari segi kelestarian penduduk dari segi ekonomi, sosial dan alam sekitar terhadap gender. Namun sebaliknya bagi Tiwi (2006) serta Johari dan Pusphavalli (2010) yang menyatakan bahawa tidak terdapat perbezaan yang signifikan dalam konsep kualiti hidup hidup di antara status jantina yang berbeza. Dari segi lokasi pula, Mohamad Shaharudin et al. (2012) menyatakan bahawa faktor lokasi sama ada bandar atau luar bandar mempengaruhi kualiti hidup penduduk yang dapat diukur melalui aspek ekonomi, kualiti perumahan, keharmonian sosial dan alam sekitar kesan transformasi pembangunan ke atas kualiti hidup masyarakat setempat (Norasyikin, 2013).

Dari segi peranan etnik pula, Johari dan Pusphavalli (2010) menyatakan bahawa tidak terdapat perbezaan dalam konsep kualiti hidup di antara jenis etnik yang berbeza. Faktor kejiranan dalam penempatan sesuatu etnik juga hubungan kekeluargaan dalam sesuatu penempatan turut menjadi penentu kepada kualiti hidup penduduk (Mohd Yusof et al., 2011). Tahap pendidikan tertinggi pula dilihat memberi perbezaan dari segi kualiti hidup penduduk seperti mana yang dinyatakan oleh Wan Maznah et al. (2016). Ini menunjukkan tahap pendidikan yang berbeza dilihat memberi kesan yang berbeza kepada kualiti hidup penduduk dimana pendidikan dilihat memberi pembangunan kepada pembangunan sosial dan ekonomi di negara ini (Hasnah et al., 2009).

Secara umumnya kajian ini bertujuan bagi mengenalpasti peranan demografi dalam kelestarian kualiti hidup penduduk di pusat penempatan kecil daerah Mualim. Faktor demografi ini dilihat membantu penyertaan anggota masyarakat dalam pembangunan. Aspek-aspek demografi yang dikaji adalah berdasarkan kepada empat perkara iaitu jantina, lokasi, etnik dan tahap pendidikan tertinggi. Setiap aspek demografi yang dikaji ini adalah saling memberi peranan dalam kualiti hidup penduduk yang meliputi tiga perkara iaitu sosial, ekonomi dan alam. Semua factor demografi ini adalah penting dan 
perlu dilaksanakan secara bertahap melalui perancangan dan dasar pembangunan. Keadaan, pencapaian, perbezaan dan faktor-faktor ini dilihat dapat memberi peluang yang besar bagi kelancaran program-program pembangunan yang dicadangkan. Justeru, kajian ini melibatkan lima buah pusat petempatan kecil dalam daerah Muallim iaitu Behrang Stesen, Behrang 2020, Proton City, Slim River dan Tanjong Malim. Kelestarian pusat penempatan kecil ini dianalisis dan dinilai dengan menggunakan 24 indikator yang terdiri dari tiga sub utama iaitu ekonomi, sosial dan alam sekitar.

\section{METOD KAJIAN}

\section{Populasi dan sampel kajian}

Kajian ini melibatkan 500 responden yang tinggal di lima buah pusat petempatan kecil dalam daerah Muallim iaitu Behrang Stesen, Behrang 2020, Proton City, Slim River dan Tanjong Malim. Pemilihan responden adalah dengan menggunakan persampelan rawak berlapis iaitu dengan melibatkan 100 orang responden bagi setiap pusat penempatan kecil kajian.

\section{Instrumen Kajian}

Kajian ini merupakan sebuah kajian tinjauan dengan menggunakan instrumen soal selidik untuk menganalisis kualiti hidup penduduk di daerah Muallim yang merangkumi lima buah pusat penempatan kecil di negeri Perak iaitu Behrang Stesen, Behrang 2020, Proton City, Slim River dan Tanjong Malim. Soal selidik dibentuk berdasarkan kepada sepuluh bidang utama Indeks Kualiti Hidup Malaysia tahun 2011. Terdapat lima bahagian utama yang terkandung dalam soal selidik kajian ini yang meliputi latar belakang responden, aspek ekonomi, sosial, persekitaran dan kualiti hidup. Bahagian A bertujuan mendapatkan maklumat tentang latar belakang responden. Bahagian B melibatkan pemboleh ubah kajian iaitu kelestarian sosial yang mengandungi 11 item. Bahagian $\mathrm{C}$ melibatkan pemboleh ubah kedua iaitu kelestarian ekonomi terdiri daripada enam item yang merangkumi pendapat responden berhubung kelestarian ekonomi di kawasan pusat penempatan kecil yang dikaji. Bahagian D pula melibatkan pemboleh ubah kelestarian alam sekitar terdiri daripada lima item berhubung kelestarian alam sekitar di kawasan petempatan kecil yang dikaji. Kesemua item diukur dalam bentuk skala Likert empat mata iaitu 1- sangat tidak setuju, 2- tidak setuju, 3-setuju, dan 4-sangat setuju.

Jadual 1. Bahagian dalam soal selidik kajian

\begin{tabular}{cll}
\hline Bahagian & Aspek yang diukur / Pemboleh ubah & Sumber \\
\hline A & Latar belakang responden & Diubahsuai mengikut keperluan kajian \\
B & Kelestarian sosial & Diambil dan diubahsuai daripada Indeks Kualiti \\
& Kelestarian ekonomi & Hidup Malaysia Unit Perancang Ekonomi, \\
C & Jabatan Perdana Menteri (2011). \\
D & Kelestarian alam sekitar & \\
\hline
\end{tabular}

\section{Analisis Kajian}

Analisis kajian adalah dengan menggunakan ujian $\mathrm{t}$ dan ANOVA. Ujian $\mathrm{t}$ digunakan untuk membandingkan di antara dua min bagi suatu pemboleh ubah bebas iaitu sama ada terdapat perbezaan yang signifikan atau tidak terhadap pemboleh ubah bersandar. Sekiranya nilai p lebih kecil daripada nilai $\alpha$, maka min sampel adalah berbeza secara signifikan daripada nilai yang dinyatakan. Ujian ANOVA pula bertujuan untuk menilai perbezaan min pemboleh ubah bersandar kuantitatif antara tiga atau lebih kumpulan. Dalam analisis ANOVA, pemboleh ubah bersandar dan pemboleh ubah bebas 
dinamakan sebagai faktor. Faktor perlu terdiri daripada dua atau lebih peringkat (Norizan et al., 2010). Bagi tujuan penolakan atau penerimaan hipotesis, nilai $\mathrm{F}$ akan dirujuk pada aras $\mathrm{p}<0.05$.

\section{Lokasi}

Kajian ini melibatkan responden yang tinggal di dalam kawasan lima pusat penempatan kecil di daerah Muallim yang merupakan daerah kesebelas di negeri Perak. Sebelum ini, daerah ini adalah sebahagian daripada daerah Batang Padang yang merangkumi tiga mukim iaitu Slim, Hulu Bernam Timur dan Hulu Bernam Barat. Kawasan-kawasan yang dirangkumi daerah ini termasuk Tanjung Malim, Trolak, Slim, Proton City dan sebahagian Behrang yang terletak di sepanjang Lebuh Raya Utara Selatan (PLUS). Kedudukan daerah Muallim terletak di hujung tenggara negeri Perak, berdasarkan sempadan mukim Slim, Hulu Bernam Timur dan Hulu Bernam Barat (Rajah 1). Selain itu, daerah ini juga dikenali daerah belia di mana merupakan wilayah ilmu dan kota pelajar bertepatan dengan maksud perkataan mualim iaitu ilmu dan agama.

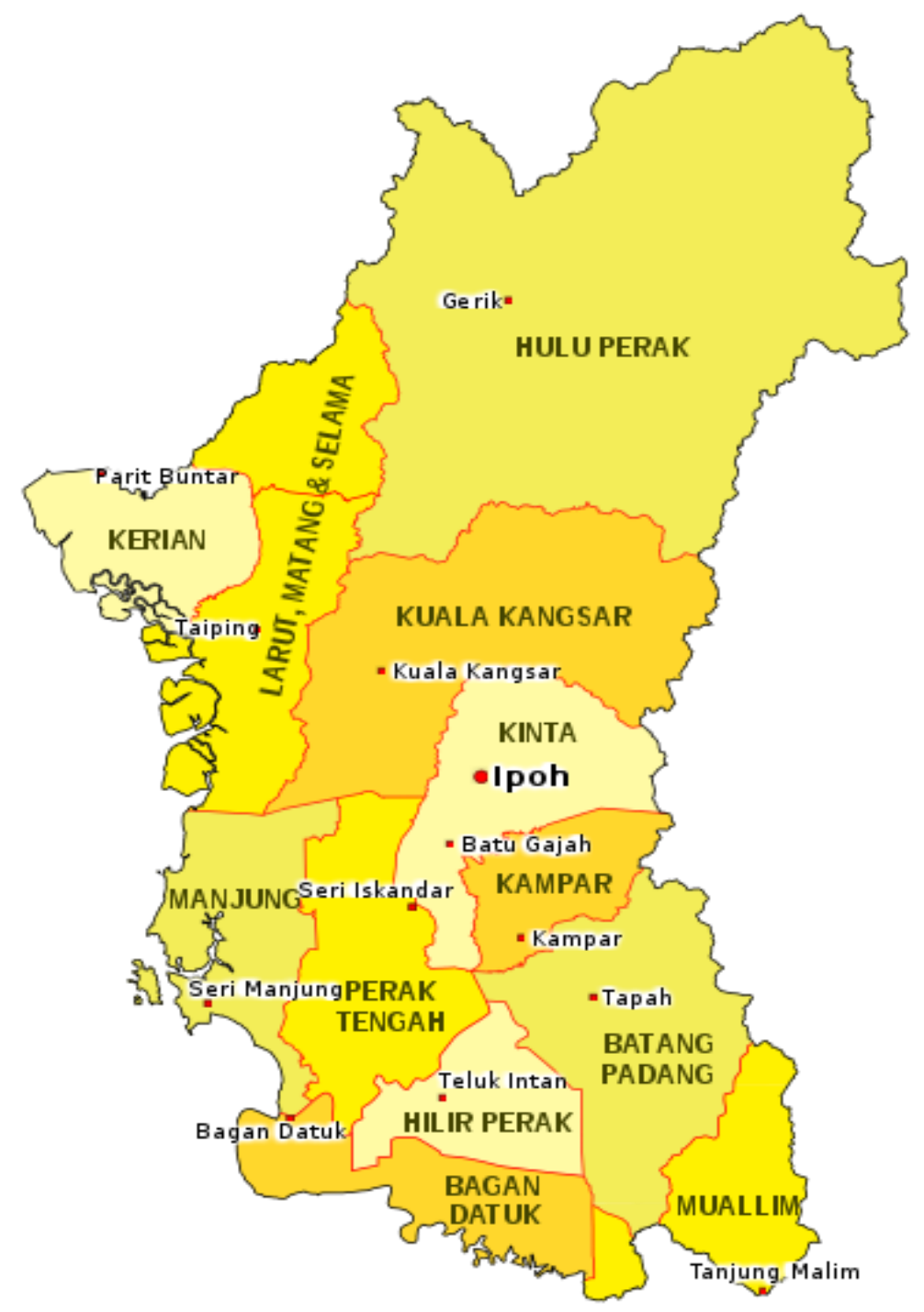

Rajah 1. Kedudukan daerah Muallim dalam peta negeri Perak Sumber: Pejabat Tanah dan Daerah Muallim (2017) 
Perbezaan kualiti hidup penduduk berdasarkan ciri demografi di pusat petempatan kecil: Kajian kes daerah Muallim, Perak, Malaysia

\section{HASIL DAN PERBINCANGAN KAJIAN}

\section{Latar Belakang Responden}

Jadual 3 menunjukkan latar belakang responden yang tinggal di lima pusat penempatan kecil di daerah Muallim meliputi tiga perkara iaitu jantina, etnik dan tahap pendidikan tertinggi. Taburan jantina responden menunjukkan seramai 295 orang (59\%) terdiri daripada responden lelaki manakala selebihnya responden perempuan iaitu seramai 205 orang (41\%). Bagi etnik responden, seramai 359 orang $(71.8 \%)$ terdiri daripada etnik Melayu, 74 orang (14.8\%) etnik Cina, 60 orang (12.0\%) etnik India dan lain-lain seramai tujuh orang (1.4\%). Seterusnya bagi tahap pendidikan responden, kebanyakan mempunyai pendidikan sehingga sekolah menengah dengan bilangan 200 orang (40\%), diikuti dengan pendidikan peringkat diploma seramai 133 orang (26.6\%), seterusnya pendidikan sehingga ijazah sarjana muda seramai 95 orang $(19.0 \%)$, pendidikan sehingga sekolah rendah seramai 54 orang $(10.8 \%)$, peringkat ijazah sarjana seramai 13 orang $(2.6 \%)$ dan yang terakhir pendidikan tertinggi doktor falsafah seramai seorang $(0.2 \%)$.

Jadual 3 Jantina responden mengikut kawasan pusat penempatan kecil

\begin{tabular}{|c|c|c|c|c|c|c|c|c|}
\hline \multicolumn{2}{|c|}{ Latar Belakang Responden } & \multicolumn{7}{|c|}{ Kekerapan/Peratusan (\%) Responden mengikut Pusat penempatan kecil } \\
\hline & & $\begin{array}{c}\text { Behrang } \\
2020\end{array}$ & $\begin{array}{l}\text { Behrang } \\
\text { Stesen }\end{array}$ & $\begin{array}{c}\text { Proton } \\
\text { City }\end{array}$ & $\begin{array}{l}\text { Slim } \\
\text { River }\end{array}$ & $\begin{array}{l}\text { Tanjong } \\
\text { Malim }\end{array}$ & $\begin{array}{c}\text { Jumlah } \\
\text { Keseluruhan }\end{array}$ & $\begin{array}{l}\text { Peratus } \\
\text { Keseluruhan } \\
(\%)\end{array}$ \\
\hline \multirow[t]{3}{*}{ Jantina } & Lelaki & 62 & 55 & 70 & 53 & 55 & 295 & 59.0 \\
\hline & Perempuan & 38 & 45 & 30 & 47 & 45 & 205 & 41.0 \\
\hline & Jumlah & 100 & 100 & 100 & 100 & 100 & 500 & 100.0 \\
\hline \multirow[t]{5}{*}{ Etnik } & Melayu & 90 & 53 & 87 & 60 & 69 & 359 & 71.8 \\
\hline & Cina & 3 & 29 & 5 & 22 & 15 & 74 & 14.8 \\
\hline & India & 6 & 15 & 6 & 17 & 16 & 60 & 12.0 \\
\hline & Lain-lain & 1 & 3 & 2 & 1 & 0 & 7 & 1.4 \\
\hline & Jumlah & 100 & 100 & 100 & 100 & 100 & 500 & 100.0 \\
\hline \multirow{9}{*}{$\begin{array}{l}\text { Tahap } \\
\text { pendidikan }\end{array}$} & Sekolah & 3 & 27 & 2 & 9 & 13 & 54 & 10.8 \\
\hline & Rendah & & & & & & & \\
\hline & $\begin{array}{l}\text { Sekolah } \\
\text { Menengah }\end{array}$ & 46 & 40 & 22 & 44 & 48 & 200 & 40.0 \\
\hline & Diploma & 39 & 22 & 27 & 21 & 24 & 133 & 26.6 \\
\hline & $\begin{array}{l}\text { Ijazah Sarjana } \\
\text { Muda }\end{array}$ & 12 & 11 & 38 & 23 & 11 & 95 & 19.0 \\
\hline & Ijazah Sarjana & 0 & 0 & 7 & 3 & 3 & 13 & 2.6 \\
\hline & Doktor & 0 & 0 & 0 & 0 & 1 & 1 & 0.2 \\
\hline & Falsafah & & & & & & & \\
\hline & Jumlah & 100 & 100 & 100 & 100 & 100 & 500 & 100.0 \\
\hline
\end{tabular}

\section{Analisis Perbezaan Pemboleh Ubah Ekonomi, Sosial dan Persekitaran Dengan Jantina, Etnik Dan Tahap Pendidikan}

i. $\quad$ Ujian t pemboleh ubah ekonomi, sosial dan persekitaran terhadap jantina

Berdasarkan Jadual 2, dapatan ujian-t menunjukkan bahawa tidak terdapat perbezaan yang signifikan dalam pemboleh ubah ekonomi dalam kalangan lelaki $(\min =2.75, \mathrm{SP}=0.38, \mathrm{n}=227)$ dengan perempuan $(\min 2.97, \mathrm{SP}=0.39, \mathrm{n}=240)$ iaitu $\mathrm{t}=-6.07, \mathrm{df}=465, \mathrm{p}<0.05$. Seterusnya bagi pemboleh ubah ekonomi antara lelaki dengan perempuan, dapatan menunjukkan terdapat perbezaan antara tahap ekonomi dimana lelaki $(\min =2.64, \mathrm{SP}=0.46, \mathrm{n}=227)$ dengan perempuan $(\min 2.80, \mathrm{SP}=0.47, \mathrm{n}=240)$ iaitu $\mathrm{t}=-$ $3.73, \mathrm{df}=465, \mathrm{p}>0.05$. Bagi pemboleh ubah alam sekitar pula, skor min lelaki ialah 2.82 manakala skor min bagi perempuan ialah 3.00. Sub pemboleh ubah ini menunjukkan terdapat perbezaan yang signifikan iaitu berada pada tahap $0.011(\mathrm{t}=-3.50, \mathrm{df}=465, \mathrm{p}<0.05)$. 
Ini menunjukkan bahawa hanya sub pemboleh ubah ekonomi sahaja yang memberi perbezaan dari segi jantina manakala tidak bagi sosial dan alam sekitar. Dapatan ini adalah selari dengan pendapat Johari dan Pusphavalli (2010) yang menunjukkan bahawa tidak terdapat perbezaan yang signifikan dalam konsep kualiti hidup di antara status jantina yang berbeza. Tiwi (2006) juga berpendapat bahawa tidak wujud perbezaan kualiti hidup dari segi alam sekitar di antara jantina. Kajian oleh Namun begitu dapatan Habibah dan Punitha (2012) pula menyatakan sebaliknya bahawa terdapat perbezaan dari segi kelestarian ekonomi, sosial dan alam sekitar terhadap gender.

Jadual 2 Perbezaan pemboleh ubah ekonomi, sosial dan alam sekitar berdasarkan jantina

\begin{tabular}{llllllcc}
\hline Pemboleh ubah & Jantina & N & Min & SP & df & t & $p$ \\
\hline \multirow{2}{*}{ Sosial } & Lelaki & 227 & 2.75 & 0.38 & 465 & -6.07 & .042 \\
\multirow{2}{*}{ Ekonomi } & Perempuan & 240 & 2.97 & 0.39 & & & \\
& Lelaki & 227 & 2.64 & 0.46 & 465 & -3.73 & .393 \\
Alam Sekitar & Perempuan & 240 & 2.80 & 0.47 & & & \\
& Lelaki & 227 & 2.82 & 0.59 & 465 & -3.50 & .011 \\
\hline
\end{tabular}

ii. Ujian ANOVA pemboleh ubah ekonomi, sosial dan persekitaran terhadap lokasi

Jadual 3 menunjukkan dapatan ujian ANOVA satu hala pemboleh ubah ekonomi, sosial dan alam sekitar terhadap lokasi. Pemboleh ubah ekonomi menunjukkan terdapat perbezaan antara kumpulan lokasi $(\min =2.70)$ dan dalam kumpulan lokasi $(\min =0.15)$, iaitu nilai $\mathrm{F}=18.168$ dengan $\mathrm{p}=0.00$. Manakala bagi pemboleh ubah sosial turut menunjukkan perbezaan mengikut lokasi antara kumpulan $(\min =0.88)$ dan dalam kumpulan $(\min =0.22)$, iaitu nilai $\mathrm{F}=4.05$ dengan $\mathrm{p}=0.003$. Seterusnya, bagi pemboleh ubah alam sekitar menunjukkan terdapat perbezaan mengikut lokasi antara kumpulan ( $\min =1.358)$ dan dalam kumpulan $(\min =0.29$ ), iaitu nilai $\mathrm{F}=4.62$ dengan $\mathrm{p}=0.001$.

Maka ini menunjukkan terdapat perbezaan dari segi lokasi tempat tinggal responden yang merangkumi tiga mukim iaitu Slim, Hulu Bernam Timur dan Hulu Bernam Barat bagi ketiga-tiga pemboleh ubah kajian. Dapatan ini adalah selari dengan dapatan Noralina (2018) yang menyatakan bahawa faktor lokasi memberi perbezaan kepada kualiti hidup penduduk di sesuatu kawasan. Selain itu Mohamad Shaharudin et al. (2012) juga turut menyatakan bahawa faktor lokasi sama ada bandar atau luar bandar turut mempengaruhi kualiti hidup penduduk kawasan yang dikaji. kualiti hidup penduduk di lokasi ini dapat diukur melalui aspek ekonomi, kualiti perumahan, keharmonian sosial dan alam sekitar akibat daripada kesan transformasi pembangunan ke atas kualiti hidup masyarakat setempat (Norasyikin, 2013).

Jadual 3 Perbezaan pemboleh ubah ekonomi, sosial dan persekitaran berdasarkan lokasi

\begin{tabular}{llccccc}
\hline Pemboleh ubah & Punca Variasi & JKD & dk & MKD & F & $p$ \\
\hline \multirow{3}{*}{ Ekonomi } & Antara Kumpulan & 10.81 & 4 & 2.70 & 18.17 & .000 \\
& Dalam Kumpulan & 73.62 & 495 & 0.15 & & \\
\multirow{3}{*}{ Sosial } & Jumlah & 84.43 & 499 & & & .003 \\
& Antara Kumpulan & 3.53 & 4 & 0.88 & 4.05 & \\
\multirow{4}{*}{ Alam Sekitar } & Dalam Kumpulan & 107.78 & 495 & 0.22 & & \\
& Jumlah & 111.30 & 499 & & & .001 \\
& Antara Kumpulan & 5.43 & 4 & 1.36 & 4.62 & \\
\hline
\end{tabular}

iii. Ujian ANOVA pemboleh ubah ekonomi, sosial dan persekitaran terhadap etnik

Jadual 4 menunjukkan dapatan ujian ANOVA satu hala pemboleh ubah ekonomi, sosial dan alam sekitar terhadap etnik. Pemboleh ubah ekonomi menunjukkan terdapat perbezaan antara kumpulan etnik responden $(\min =0.63)$ dan dalam kumpulan etnik $(\mathrm{min}=0.17)$, iaitu nilai $\mathrm{F}=3.81$ dengan $\mathrm{p}=0.10$. Manakala bagi pemboleh ubah sosial turut menunjukkan perbezaan mengikut etnik antara kumpulan 
$(\min =2.35)$ dan dalam kumpulan $(\min =0.21)$, iaitu nilai $\mathrm{F}=11.16$ dengan $\mathrm{p}=0.000$. Seterusnya, bagi pemboleh ubah alam sekitar menunjukkan terdapat perbezaan mengikut etnik antara kumpulan $(\min =2.02)$ dan dalam kumpulan ( $\min =0.29)$, iaitu nilai $\mathrm{F}=6.9$ dengan $\mathrm{p}=0.000$.

Maka ini menunjukkan terdapat perbezaan dari segi etnik Melayu, Cina, India dan lain-lain bagi ketigatiga pemboleh ubah kajian. Namun begitu, kajian oleh Johari dan Pusphavalli (2010) pula menunjukkan sebaliknya iaitu tidak terdapat perbezaan yang signifikan dalam konsep kendiri dan kualiti hidup di antara status etnik yang berbeza. Ini menunjukkan bahawa usaha dalam pemencahan berkelompok pembinaan kawasan perumahan bagi meningkatkan kualiti hidup mengikut etnik di Malaysia adalah suatu yang mencabar usaha kesepaduan dan penyatupaduan masyarakat plural (Kartini, 2016).

Jadual 4 Perbezaan pemboleh ubah ekonomi, sosial dan persekitaran berdasarkan etnik

\begin{tabular}{llccccc}
\hline Pemboleh ubah & Punca Variasi & JKD & dk & MKD & F & $p$ \\
\hline \multirow{3}{*}{ Ekonomi } & Antara Kumpulan & 1.90 & 3 & 0.63 & 3.81 & .010 \\
& Dalam Kumpulan & 82.53 & 496 & 0.17 & & \\
Sosial & Jumlah & 84.43 & 499 & & & \\
& Antara Kumpulan & 7.04 & 3 & 2.35 & 11.16 & .000 \\
& Dalam Kumpulan & 104.26 & 496 & 0.21 & & \\
Alam Sekitar & Jumlah & 111.30 & 499 & & & .000 \\
& Antara Kumpulan & 6.06 & 3 & 2.02 & 6.90 & \\
\hline
\end{tabular}

iv. Ujian ANOVA pemboleh ubah ekonomi, sosial dan persekitaran terhadap tahap pendidikan

Jadual 5 menunjukkan dapatan ujian ANOVA satu hala pemboleh ubah ekonomi, sosial dan alam sekitar terhadap tahap pendidikan tertinggi. Pemboleh ubah ekonomi menunjukkan terdapat perbezaan antara kumpulan tahap pendidikan tertinggi $(\mathrm{min}=0.68)$ dan dalam kumpulan tahap pendidikan tertinggi ( $\min =0.16$ ), iaitu nilai $\mathrm{F}=4.13$ dengan $\mathrm{p}=0.001$. Manakala bagi pemboleh ubah sosial turut menunjukkan perbezaan mengikut tahap pendidikan tertinggi antara kumpulan $(\mathrm{min}=2.53)$ dan dalam kumpulan (min=0.20), iaitu nilai $\mathrm{F}=12.69$ dengan $\mathrm{p}=0.000$. Seterusnya, bagi pemboleh ubah alam sekitar dapatan menunjukkan terdapat perbezaan mengikut tahap pendidikan tertinggi antara kumpulan ( $\min =1.03$ ) dan dalam kumpulan ( $\min =0.30$ ), iaitu nilai $\mathrm{F}=3.48$ dengan $\mathrm{p}=0.004$.

Maka ini menunjukkan terdapat perbezaan dari segi tahap pendidikan tertinggi bagi ketiga-tiga pemboleh ubah kajian yang selari dengan dapatan kajian Wan Maznah et al. (2016) yang menunjukkan terdapat perbezaan kualiti hidup yang signifikan mengikut tahap pendidikan. Tahap kualiti hidup ini dapat diukur berdasarkan kepada pendapatan bulanan, tahap pendidikan, pemilikan rumah dan pemilikan produk kewangan (Zaimah et al., 2012). Justeru, tahap pendidikan yang berbeza dilihat memberi kesan yang berbeza kepada kualiti hidup penduduk dimana pendidikan dilihat memberi pembangunan kepada ekonomi di Malaysia (Hasnah et al., 2009).

Jadual 5 Perbezaan pemboleh ubah ekonomi, sosial dan persekitaran berdasarkan tahap Pendidikan

\begin{tabular}{llccccc}
\hline Pemboleh ubah & Punca Variasi & JKD & dk & MKD & F & $p$ \\
\hline \multirow{3}{*}{ Ekonomi } & Antara Kumpulan & 3.39 & 5 & 0.68 & 4.13 & .001 \\
& Dalam Kumpulan & 81.05 & 494 & 0.16 & & \\
Sosial & Jumlah & 84.43 & 499 & & & \\
& Antara Kumpulan & 12.67 & 5 & 2.53 & 12.69 & .000 \\
& Dalam Kumpulan & 98.64 & 494 & 0.20 & & \\
Alam Sekitar & Jumlah & 111.30 & 499 & & & \multirow{2}{*}{004} \\
& Antara Kumpulan & 5.14 & 5 & 1.03 & 3.48 & \\
\hline
\end{tabular}




\section{KESIMPULAN}

Berdasarkan dapatan dan perbincangan dalam artikel ini, jelas menunjukkan tidak terdapat perbezaan yang signifikan antara jantina dari segi sowial dan alam sekitar, manakala bagi lokasi terdapat perbezaan yang signifikan bagi ketiga-tiga pemboleh ubah kajian. Dari segi perbezaan etnik dan tahap pendidikan tertinggi pula menunjukkan ketiga-tiga pemboleh ubah kajian terdapat perbezaan terhadap kualiti hidup penduduk di kawasan kajian. Secara keseluruhannya dapat dirumuskan bahawa jantina memberi peranan kepada kualiti hidup penduduk dalam daerah Muallim namun tidak bagi lokasi, etnik dan tahap pendidikan. Penemuan ini menunjukkan bahawa terdapat sedikit jurang dalam konteks kualiti hidup penduduk dalam daerah Mualim terutamanya dari segi lokasi, etnik dan tahap pendidikan. Justeru, bagi mengurangkan jurang ini penglibatan dalam kalangan masyarakat awam, agensi kerajaan, institusi perniagaan, institusi pendidikan, media sosial membantu secara langsung membangunkan pusat petempatan kecil ini dalam menyamatarafkan ketiga-tiga kategori ini iaitu lokasi, etnik dan tahap pendidikan tertinggi agar tercapai kelestarian dalam konteks kualiti hidup penduduk selari dengan misi pembangunan daerah Muallim yang merupakan hub automotif di peringkat nasional.

\section{RUJUKAN}

Abdul Samad, H, Shaharudin, I dan Abdul Hadi (2004). Persekitaran Bandar Lestari untuk Kesejahteraan Komuniti. Malaysian Journal of Environmental Management. Vol. 5 (2004): 3 - 29

Ahmad Shukri, M. N. \& Rosman, M.Y. (2003). Konsep, teori, dimensi \& isu pembangunan. Skudai, Johor: Penerbit Universiti Teknologi Malaysia.

Fatimah, Y., Katiman, R. \& Zikri, M. (2008). Bandar berdaya saing vis-a-vis pembangunan bandar Lestari: Satu wacana tentang pembangunan bandar di Malaysia. Jurnal Masyarakat dan Ruangan di Malaysia, 4(3), 85-98.

Garau, C. \& Pavan, V.M. (2018). Evaluating Urban Quality: Indicators and Assessment Tools for Smart Sustainable Cities. Sustainability 10, 575.

Habibah, L. \& Punitha, M. (2012). Amalan pengajaran pendidikan alam sekitar di Institut Pendidikan Guru, Kampus Pulau Pinang. GEOGRAFIA Malaysia Journal of Society and Space, 8(2), 1 - 6.

Hasnah, A., Luqman, A., Sanep, A. \& Noraziah, A. (2009). Keperluan, kepentingan dan sumbangan perancangan pendidikan dalam pembangunan ekonomi Malaysia. Jurnal e-Bangi, 4(1), 13-29.

Johari, H. \& Pusphavalli, R. (2010). Hubungan di antara konsep kendiri dan kualiti hidup di kalangan remaja akhir. Skudai, Johor: Penerbit Universiti Teknologi Malaysia.

Kartini, A. T. (2016). Konsep, dasar dan perlaksanaan Bandar Sejahtera dengan rujukan khas kepada Malaysia. GEOGRAFIA Malaysian Journal of Society and Space, 12(7), 26 - 33.

Katiman Rostam (2002). Pengantar geografi bandar. Kuala Lumpur: Dewan Bahasan dan Pustaka.

Knox, P.L. \& Mayer, H. (2009). Small town sustainability: Economic, sosial and environment innovation. Berlin: Birkhauser Verlag AG.

Mohamad Shaharudin, S., Mohd Yusof, H., Azima, A. M., Rosniza, A., Novel, L. \& Mohd Fuad, M.J. (2012). Isu keselamatan dalam kesejahteraan komuniti 'kampung dalam bandar' di Bandaraya Alor Setar, Kedah Darul Aman. GEOGRAFIA Malaysia Journal of Society and Space, 8(8), 112 - 120.

Mohd Yusof, H., Mohamad Shaharudin, S., Suraiya, I. \& Abd. Hair, A. (2011). Hubungan kejiranan dalam membentuk kualiti hidup masyarakat 'kampung bandar': Kes Kampung Berjaya dan Kampung Mempelam, Alor Setar, Malaysia. GEOGRAFIA Malaysian Journal of Society and Space, 7(3), 36 - 44.

Noralina. (2018). Ekologi keluarga dan kualiti hidup kanak-kanak miskin di Malaysia. (Tesis PhD). Fakulti Sastera dan Sains Sosial, Universiti Malaya.

Nor-Ina, K., Norizan, M.N. \& Ruslan, R. (2010). Jenayah dan perbandaran: Satu kajian di Daerah Timur Laut Pulau Pinang. Dalam: Yazid S, Fauziah CL, Mazdi M (eds) Isu-isu semasa alam sekitar manusia di Malaysia, ms 43-60. Universiti Pendidikan Sultan Idris, Perak Darul Rizduan.

Norizan, E., Nordin, A. R., \& Mohd Ali, S. (2010). Kajian tinjauan (secara kuantitatif). Dlm Noraini, I. (ed.) Penyelidikan dalam Pendidikan, ms 196-214. Kuala Lumpur: McGraw-Hill.

Nurasyikin, M. \& Haryati, S. (2013). Tranformasi pembangunan luar bandar: Kesan ke atas kualiti hidup masyarakat. Johor Bahru: Universiti tun Hussein Onn.

Rosmin, T. (2007). Pembangunan pusat perkhidmatan hierarki rendah: Kes Pusat Pertumbuhan Desa (PPD), di Negeri Kedah, Malaysia (Tesis PhD). Fakulti Sains Sosial dan Kemanusiaan, Universiti Kebangsaan Malaysia. (Tidak diterbitkan). 
Perbezaan kualiti hidup penduduk berdasarkan ciri demografi di pusat petempatan kecil: Kajian kes daerah Muallim, Perak, Malaysia

Tiwi, K. (2006). Perkaitan antara pengetahuan dan sikap terhadap alam sekitar di kalangan guru pelatih Maktab Perguruan Batu Lintang. Jurnal Penyelidikan IPBL, 7, 61-77.

Unit Perancang Ekonomi Jabatan Perdana Menteri. (2015). Rancangan Malaysia pertama hingga kesebelas. Putrajaya: Unit Perancang Ekonomi Jabatan Perdana Menteri. Diperoleh daripada http://epu.gov.my/ms/rmk/rancangan-malaysia-pertama.

Unit Perancang Ekonomi, Jabatan Perdana Menteri (2011). Indeks Kualiti Hidup Malaysia 2011. Putrajaya: Unit Perancang Ekonomi, Jabatan Perdana Menteri.

Wan Maznah, W. H., Azahan, A. \& Shamsuddin, M. (2016). Kualiti hidup dan tahap pendidikan isi rumah di pinggir bandar di Malaysia: Satu penerokaan isi rumah di Mukim Rawang II, Selangor. GEOGRAFIA Malaysian Journal of Society and Space, 12(9), 92 - 103.

Wan Rozali, W. H. (2003). Kualiti hidup sosial dan proses perbandaran di Malaysia. Pulau Pinang: Universiti Sains Malaysia.

White, R. \& Whitney, J. (1992). Cities and environment: an over- view. In Sustainable Cities: urbanization and the environment in international perspective (eds). Stren, R, White, R. \& Whitney, D. ms 8-52. Westview, Boulder, CO.

Yazid, S., Hanifah, M., Mohmadisa, H. \& Nasir, N. (2015). Kelestarian pusat penempatan kecil Wilayah Lembah Bernam dari perspektif kesejahteraan penduduk. Geografi, 3(2), 28-36.

Zaimah, R., Sarmila, M.S., Azima, A.M., Suhana, S., Mohd Yusof, H. \& Lyndon, N. (2012). Kualiti hidup dan kesejahteraan belia: Kajian ke atas pekerja sektor awam Malaysia. GEOGRAFIA Malaysia Journal of Society and Space, 8(6), $150-156$.

Zaini, U. (2009). Minda lestari: Pembangunan negara dan pemuliharaan alam sekitar. Skudai: Penerbit Universiti Teknologi Malaysia. 